\title{
Preparation and evaluation of carbon-supported catalysts for ethanol oxidation
}

\author{
A. Bonesi - M. Asteazaran - M. S. Moreno - G. Zampieri • \\ S. Bengio $\cdot$ W. Triaca $\cdot$ A. M. Castro Luna
}

\begin{abstract}
Supported PtSnIr/C, PtSn/C, and IrSn/C catalysts with potential application in a direct alcohol fuel cell were prepared by chemical reduction employing Pechini methodology. The catalyst particles were characterized by high-resolution transmission electron microscopy, energy-dispersive X-ray spectroscopy, and X-ray photoelectron spectroscopy (XPS). Linear sweep voltammetry (LV), chronoamperometry, and electrochemical impedance spectroscopy (EIS) measurements were performed by using a glassy carbon working electrode covered with the catalyst in a $1 \mathrm{M}$ ethanol $+0.5 \mathrm{M} \mathrm{H}_{2} \mathrm{SO}_{4}$ solution at $60{ }^{\circ} \mathrm{C}$. It was demonstrated through XPS that PtSnIr/C and $\mathrm{IrSn} / \mathrm{C}$ contain both $\mathrm{IrO}_{2}$ and $\mathrm{SnO}_{2}$. $\mathrm{LV}$ and chronoamperometry show a better catalytic behavior for ethanol oxidation on $\mathrm{PtSnIr} / \mathrm{C}$ in the low-potential region and the improvement is attributed to the presence of both Sn and Ir oxides. The EIS accurately established that PtSnIr/C improved ethanol oxidation at lower potentials than $\mathrm{PtSn} / \mathrm{C}$.
\end{abstract}

Keywords Platinum - Iridium · Tin - Ethanol - DEFC . Nanoparticles $\cdot$ Electrochemical impedance spectroscopy

A. Bonesi · M. Asteazaran · W. Triaca · A. M. Castro Luna $(\bowtie)$ Instituto de Investigaciones Fisicoquímicas Teóricas y Aplicadas (INIFTA), Facultad de Ciencias Exactas, UNLP-CONICET, La Plata, Buenos Aires, Argentina

e-mail: castrolu@gmail.com

A. M. Castro Luna

e-mail: castrolu@inifta.unlp.edu.ar

M. Asteazaran · A. M. Castro Luna

Centro de Investigación y Desarrollo en Ciencia y Tecnología de

Materiales (CITEMA), Facultad Regional La Plata, UTN,

La Plata, Argentina

M. S. Moreno $\cdot$ G. Zampieri $\cdot$ S. Bengio

Centro Atómico Bariloche, Comisión Nacional de Energía Atómica

(CAB-CNEA), Bariloche, Argentina

\section{Introduction}

Fuel cells that employ liquid alcohols such as a direct ethanol fuel cell (DEFC) are attractive to power portable devices because their theoretical cell voltage is similar to that obtained when hydrogen is oxidized [1-3] and in the case of ethanol, its complete electro-oxidation involves a 12 electron process. Unlike hydrogen, ethanol is easy to handle, transport, and store and no previous reformer system is necessary. Nevertheless, DEFC undergoes slow kinetics of alcohol oxidation on electrode surfaces. Efficiency is currently quite low for that cell [4]. To achieve the maximum chemical energy from an alcohol molecule, it should be completely oxidized to $\mathrm{CO}_{2}$. Research into alcohol fuel cell catalysis is focused primarily on increasing the catalytic efficiency of the electrode materials [5]. Platinum is considered as the most active catalyst for ethanol oxidation at low temperature. However, the main problem in achieving an efficient conversion is that ethanol oxidation can be conducted through different paths. Thus, large amounts of partially oxidized products such as acetaldehyde and acetic acid have been detected at low temperature as the main products in ethanol oxidation (EO) $[5,6]$. Moreover, strongly adsorbed species such as $\mathrm{CO}$ and $\mathrm{CH}_{\mathrm{x}}$, which are difficult to convert to $\mathrm{CO}_{2}$, block the surface and hinder further alcohol adsorption causing low-power densities at DEFC. A good ethanol catalyst should have a great capacity to electro-oxidize ethanol to $\mathrm{CO}_{2}$ and water, but $\mathrm{Pt}$ alone shows a low capability to sufficiently favor the $\mathrm{C}-\mathrm{C}$ rupture of the ethanol molecule. Therefore, the electrocatalytic concern is to cope with a material that facilitates ethanol complete oxidation and shifts the onset oxidation potential to lower values.

It appears that an improvement in EO electrocatalysis is possible with multifunctional Pt-based combinations. The superior performance of binary or ternary Pt-based catalysts relative to a pure Pt catalyst has been explained in terms of 
two models: the bifunctional mechanism and the ligand effect. In the bifunctional mechanism model, the added components to Pt provide the oxygen-containing species required for the oxidative removal of adsorbed CO-like species. The ligand effect is considered as a modification of the Pt electronic structure by the presence of the added atoms, therefore the adsorbed residues are less strongly bonded to $\mathrm{Pt}$ and consequently easier to remove [5]. In case of PtM alloy formation, the alien atom $\mathrm{M}$, can go into the Pt crystal net modifying the Pt-Pt distance and favoring adsorption and breaking of the ethanol molecule [7]. Thus, it is well known that the addition of $\mathrm{Sn}$ to $\mathrm{Pt}$ enhances the activity for $\mathrm{EO}$ particularly at lower potentials as compared to that obtained with Pt catalyst. Jiang et al. [8] established a correlation between the structures of $\mathrm{PtSn}$ alloy and $\mathrm{PtSnO}_{2}$ prepared by the polyol method and postulated that $\mathrm{SnO}_{2}$ in the vicinity of Pt has the ability to promote the oxidation of CO-like species resulting from alcohol oxidative adsorption. On the other hand, the addition of a fourth metal (Ir) in the ternary $\mathrm{PtMnCu} / \mathrm{C}$ and $\mathrm{PtMnMo} / \mathrm{C}$ leads to quaternary alloys with better catalytic activity towards EO according to Amman et al. [9]. It has also been claimed by Chen et al. that the presence of $\mathrm{IrO}_{2}$ improves methanol oxidation [10]. Moreover, Cao et al. claimed that the combination $\mathrm{Ir}_{3} \mathrm{Sn}$ is a promising alternative choice of anode catalyst for DEFC [11]. Furthermore, a significant improvement in ethylene glycol electro-oxidation with multilayer PtIr catalysts has been reported [12]. The addition of Ir seems to speed up the activation of the $\mathrm{C}-\mathrm{H}$ bonds in methanol electrooxidation [13]. In order to get a deeper knowledge of the ethanol oxidation reaction, it is important to determine the role of the catalyst components and what are their beneficial contributions to EO catalysis.

The aim of this work has been to synthesize and characterize Pt-based materials such as binary $\mathrm{PtSn} / \mathrm{C}, \mathrm{IrSn} / \mathrm{C}$, and ternary PtSnIr/C alloys and to determine the catalyst with the best activity for ethanol oxidation.

\section{Experimental}

Catalysts containing Pt, Sn, and Ir with a fixed total metal loading on carbon of $40 \mathrm{wt} \%$ were synthesized employing ethylene glycol (EG) as a reactant and reducing agent together with citric acid (CA) in line with the Pechini methodology $[14,15]$. Briefly, Pt, Ir, and Sn polymeric precursors were prepared separately by employing metallic salts, namely, $\mathrm{H}_{2} \mathrm{PtCl}_{6}, \mathrm{IrCl}_{3} \cdot x \mathrm{H}_{2} \mathrm{O}$, and $\mathrm{Sn}$ citrate, dissolved in a mixture of EG and $\mathrm{CA}$ at $90^{\circ} \mathrm{C}$ and the mixture was kept under vigorous stirring for $2-3 \mathrm{~h}$ composing a polyester network that contains the metallic ions homogeneously distributed. The CA/EG/metal molar ratio is $4: 16: 1$ for all the polymeric precursors. It appears that the citric chelate helps to prevent particle aggregation in a certain extent and induce nanoparticles to get high dispersion.

To obtain the supported catalysts, appropriate amounts of the polymeric precursors were dissolved in ethanol and a calculated amount of the functionalized carbon black support was added. Finally, the mixture precursor solution/carbon was homogenized in an ultrasonic bath and then calcinated at different temperatures under an air atmosphere, using a temperature program reaching $350{ }^{\circ} \mathrm{C}$ to get rid of organic residues [14]. Additionally, the functionalization of the support was achieved after an oxidative treatment in $70 \% \mathrm{HNO}_{3}$ solution at $140^{\circ} \mathrm{C}$ for $2 \mathrm{~h}$ according to [16].

The physical characterization of the materials was accomplished by high-resolution transmission electron microscopy (HRTEM), energy dispersive spectroscopy (EDS), and X-ray photoelectron spectroscopy (XPS).

For the electrochemical characterization, a conventional three-electrode cell was employed. The working electrode consisted of a glassy carbon disk $\left(0.071 \mathrm{~cm}^{2}\right.$ geometric area) covered by a thin layer of catalyst $\left(28 \mu \mathrm{g} \mathrm{cm}^{-2} \mathrm{Pt}\right.$ loading) embedded in a Nafion polymer electrolyte film $(0.1 \mu \mathrm{m}$ thick) [17]. A Pt foil of ca $1 \mathrm{~cm}^{2}$ geometric area was used as counter electrode and a saturated calomel electrode as reference electrode. In this work, the potentials are referred to that of the reversible hydrogen electrode.

The supporting electrolyte was $0.5 \mathrm{M} \mathrm{H}_{2} \mathrm{SO}_{4}$ and the working solutions were $1 \mathrm{M} \mathrm{C}_{2} \mathrm{H}_{5} \mathrm{OH}+0.5 \mathrm{M} \mathrm{H}_{2} \mathrm{SO}_{4}$ solutions. After assembling, the composite catalytic disk electrode was cycled in $0.5 \mathrm{M} \mathrm{H}_{2} \mathrm{SO}_{4}$ for $5 \mathrm{~min}$ at $0.10 \mathrm{~V} \mathrm{~s}^{-1}$ between 0.05 and $1.24 \mathrm{~V}$ to clean the surface. Real areas were determined by considering the anodic charge corresponding to the CO-stripping peak and assuming that $\mathrm{CO}$ is linearly adsorbed on one Pt site and taking into account that $420 \mu \mathrm{C}$ is equivalent to $1 \mathrm{~cm}^{2}$.

To determine the catalytic activity of the synthesized materials, current-potential curves for EO were recorded at $0.01 \mathrm{~V} \mathrm{~s}^{-1}$. Alcohol was added to the supporting electrolyte at $0.05 \mathrm{~V}$ and its oxidation was measured. The temporal stability of the electrode at $0.5 \mathrm{~V}$ was determined by chronoamperometry. The current densities are referred to the CO calculated real area. Electrochemical impedance spectroscopy (EIS) was also employed to identify the materials with the best EO performance. The impedance spectra were recorded by polarizing in a constant voltage mode from 0.4 to $0.85 \mathrm{~V}$ at frequencies from $100 \mathrm{kHz}$ to $10 \mathrm{mHz}$. The amplitude of the applied potential perturbation was $0.010 \mathrm{~V}$. All electrochemical measurements were performed at $60^{\circ} \mathrm{C}$.

Prior to each EIS measurement, the electrolyte was replaced by fresh solution and the electrode was cycled to get a clean and reproducible surface. A 30-min holding time was applied at each potential to approach a near steady state before the data were collected. 


\section{Results and discussion}

Physicochemical characterization

\section{HRTEM and SEM-EDS analysis}

HRTEM images of (a) PtSn/C, (b) $\mathrm{IrSn} / \mathrm{C}$, and (c) PtSnIr/C catalysts together with the corresponding histograms are shown in Fig. 1. All catalysts have a good dispersion on the carbon support and from the histograms it is inferred that the nanoparticles are well-dispersed on carbon support. The average particle size for $\mathrm{PtSn} / \mathrm{C}$ was ca $4.5 \mathrm{~nm}$, for $\mathrm{IrSn} / \mathrm{C}$ was around $6.5 \mathrm{~nm}$, and for PtSnIr/C was $5.12 \mathrm{~nm}$. It is possible that the Pechini methodology tends to produce agglomeration of particles during the calcination treatment at $350^{\circ} \mathrm{C}$. One of the causes of bad performance of a catalyst is related to activity loss due to the particle agglomeration.
The atomic percentages of the component in the binary and ternary catalysts, which are listed in Table 1, have been determined by EDS and XPS. It can be highlighted that EDS is a surface technique that goes through less than $10 \mu \mathrm{m}$, whereas XPS measures the elemental composition of the surface from the top to $10 \mathrm{~nm}$ depth. From Table 1, it can be noted that a significant surface $\mathrm{Sn}$ enrichment by segregation of $\mathrm{Sn}$ onto the surface, due to the great affinity of $\mathrm{Sn}$ for oxygen the migration of $\mathrm{Sn}$ of the catalyst towards the surface, occurs [18].

\section{XPS analysis}

The XPS analysis for the catalysts PtSnIr/C and $\mathrm{IrSn} / \mathrm{C}$ are shown in different binding energy regions. Thus, for $\mathrm{PtSnIr} / \mathrm{C}$, the sets of peaks with binding energies ranging from 70 to $80 \mathrm{eV}$ correspond to $\mathrm{Pt} 4 \mathrm{f}$ core level and those
Fig. 1 TEM micrographs and histograms for a $\mathrm{PtSn} / \mathrm{C}, \mathbf{b} \mathrm{IrSn} /$ $\mathrm{C}$, and $\mathbf{c} \mathrm{PtSnIr} / \mathrm{C}$ catalysts
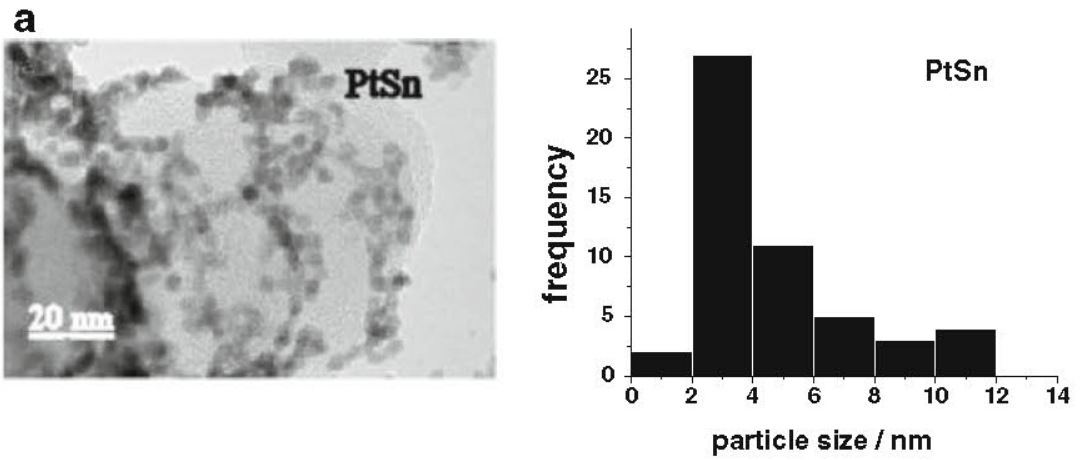

b
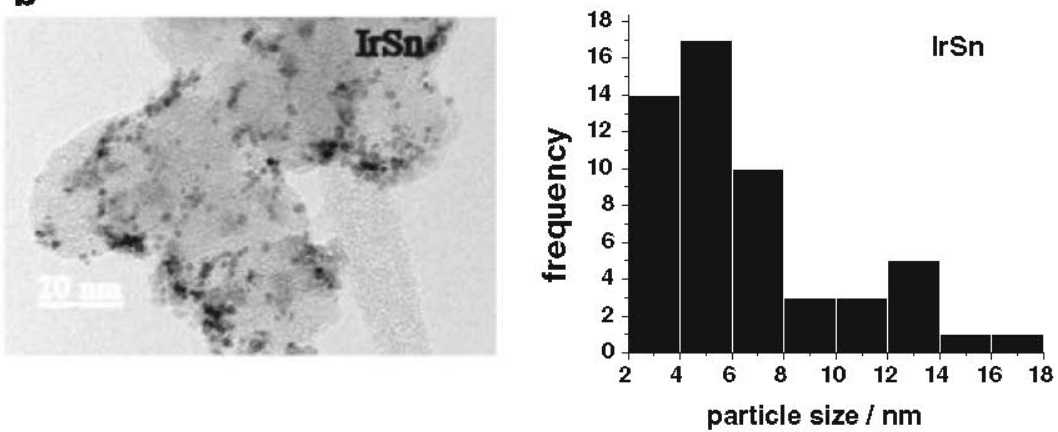

C

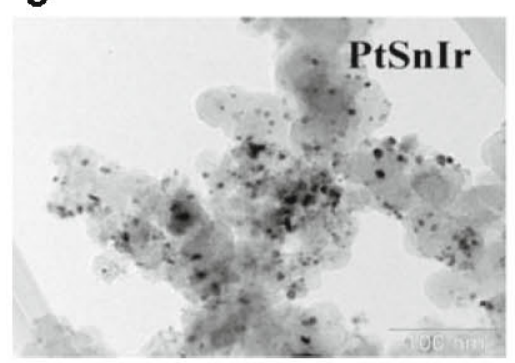

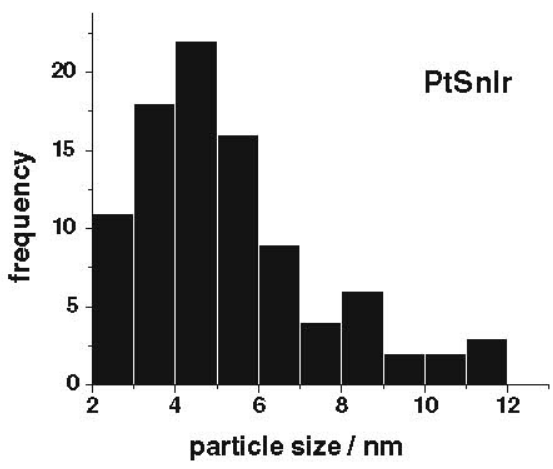


Table 1 EDX composition of the synthesized catalysts and CO stripping active area

\begin{tabular}{llll}
\hline Catalyst & $\begin{array}{l}\text { XPS \% at } \\
\text { composition }\end{array}$ & $\begin{array}{l}\mathrm{EDX} \% \text { at } \\
\text { composition }\end{array}$ & $\begin{array}{l}\text { real active surface area } \\
\text { (COstripping) } / \mathrm{cm}^{2}\end{array}$ \\
\hline PtSnIr & $\mathrm{Pt}_{1.42} \mathrm{Sn}_{1} \mathrm{Ir}_{0}$ & $\mathrm{Pt}_{3} \mathrm{Sn}_{0.48} \mathrm{Ir}_{0.64}$ & 1.21 \\
$\mathrm{IrSn}$ & $\mathrm{Ir}_{1} \mathrm{Sn}_{1.68}$ & - & 0.7 \\
$\mathrm{PtSn}$ & - & $\mathrm{Pt}_{3} \mathrm{Sn}_{1.07}$ & 1.18 \\
\hline
\end{tabular}

between 60 and $68 \mathrm{eV}$ are attributed to Ir $4 \mathrm{f}$ core level (Fig. 2a); both complex peaks can be deconvoluted into two peaks. Thus, for Ir the peak at around $61.1 \mathrm{eV}$ is ascribed to Ir (0), and the peak at $c a .63 \mathrm{eV}$ to $\mathrm{IrO}_{2}$. The relative intensities of the components were 48 and $52 \%$, respectively. The deconvoluted spectra for Pt with binding energy at 71.6 and ca $74.3 \mathrm{eV}$ were assigned to $\mathrm{Pt}(0)$ and $\mathrm{PtO}_{2}$, respectively. The relative intensities of the $\mathrm{Pt}$ components were 85 and $15 \%$, respectively. The metallic component $\mathrm{Pt}$ $(0)$ is the major component in the ternary catalyst.

In Fig. $2 b$, the $\mathrm{Sn} 3 \mathrm{~d}_{5 / 2}$ XPS spectrum of PtSnIr/C sample, in the binding energy region between 480 and $490 \mathrm{eV}$, confirms that $\mathrm{Sn}$ is mostly in an oxidized state as $\mathrm{SnO}_{2}$, according with the well-known oxophilicity of Sn [19].

For the catalyst IrSn/C, the Ir $4 f$ core level binding energy region is shown in Fig. 2c. Again, the original signal for Ir $4 f$ core level is deconvoluted into two peaks; one at $61.1 \mathrm{eV}$, attributed to Ir (0), and the other at $63.2 \mathrm{eV}$, assigned to Ir (IV). The relative intensities of the components were 70 and $30 \%$, respectively. The $\operatorname{Sn} 3 \mathrm{~d}_{5 / 2}$ core level binding energy region is depicted in Fig. $2 \mathrm{~d}$ and also confirmed that $\mathrm{Sn}$ is mostly in an oxidized state $\mathrm{SnO}_{2}$. Previous reports have shown that the electronegativity of $\mathrm{Sn}$ was lower than that of Ir, which indicates that $\mathrm{SnO}_{2}$ should be less acidic than
Fig. 2 XPS spectra for PtSnIr $a$ in the $P t 4 f$ and $I r 4 f$ energy region, $\mathbf{b}$ in the $S n 3 \mathrm{~d}_{5 / 2}$ for $\operatorname{IrSn} / \mathrm{C}, \mathrm{c}$ in the Ir $4 \mathrm{f}$ energy region, and $d$ in the $\operatorname{Sn} 3 \mathrm{~d}_{5 / 2}$
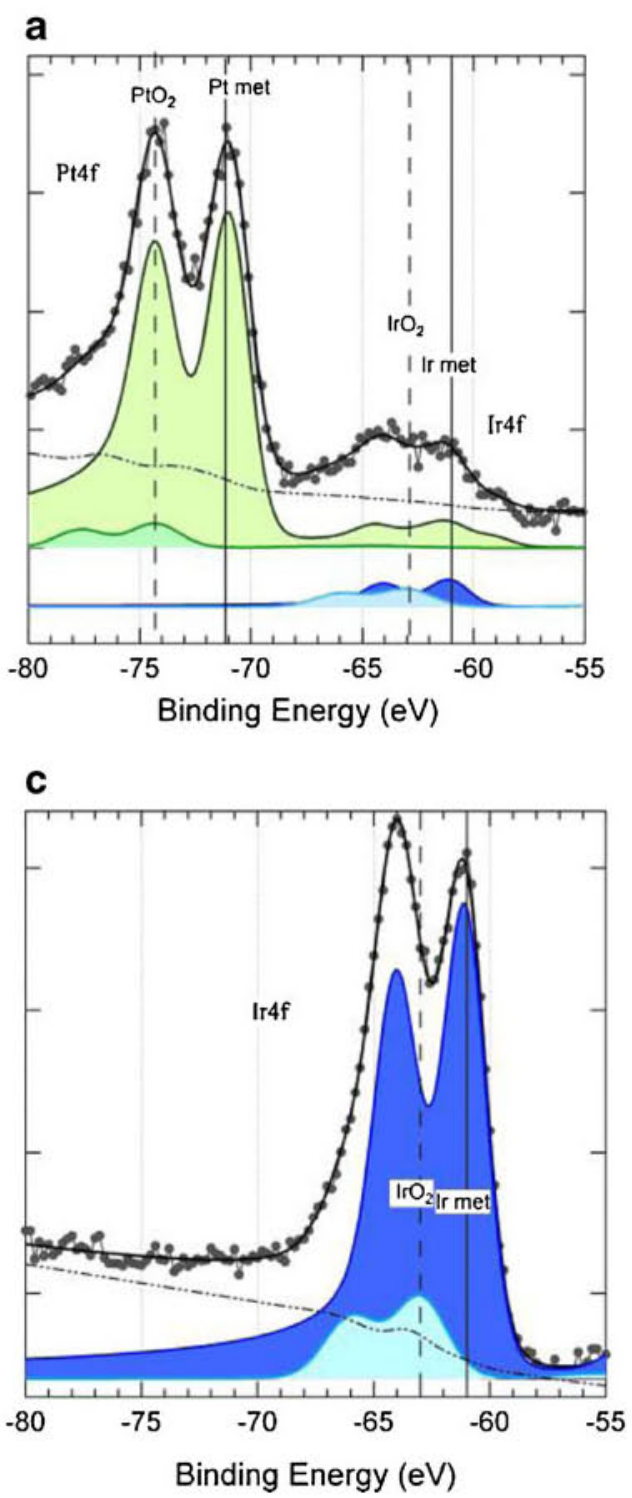
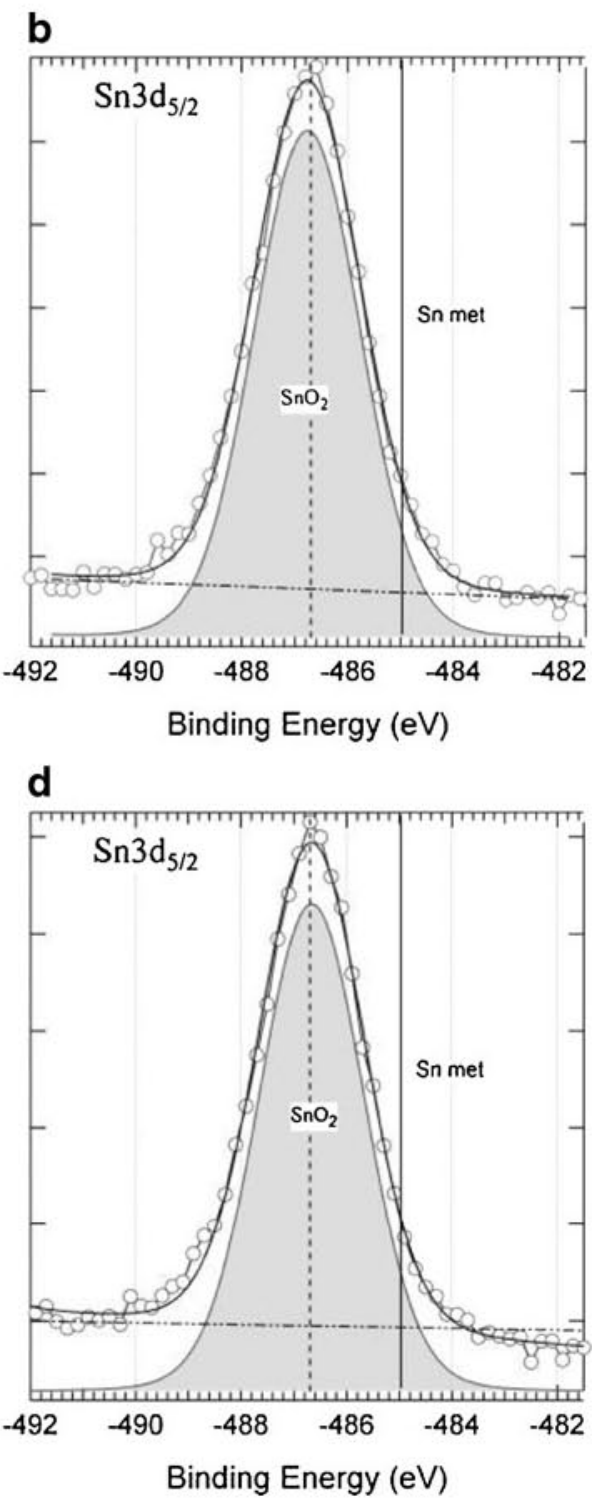
$\mathrm{IrO}_{2}[20]$. Consequently, the addition of $\mathrm{SnO}_{2}$ can effectively remove adsorbed hydroxyl species and increase the utilization ratio of the other active elements.

\section{Electrochemical characterization}

\section{Linear sweep voltammetry}

In Table 1, the real area values for all the studied catalysts obtained from de $\mathrm{CO}$ stripping experiences are shown. The areas determined for $\mathrm{PtSnIr} / \mathrm{C}$ and $\mathrm{PtSn} / \mathrm{C}$ are higher than corresponding to $\mathrm{IrSn} / \mathrm{C}$. It can be inferred from the composition of the catalysts that the increase on the electroactive area can be attributed to the presence of Pt. The CO stripping curves show an onset potential shift to lower values on the Pt-based catalysts. It can be highlighted that Stamenkovic et al. [21] claim that Sn atoms located near Pt sites may affect the adsorption characteristic of $\mathrm{Pt}$ atoms due to changes in the local potential of zero charge of $\mathrm{Pt}$ atoms near the $\mathrm{Sn}$ atoms, promoting $\mathrm{OH}$ adsorption at $\mathrm{Pt}$ sites at a lower electrode potential than pure $\mathrm{Pt}$ and therefore the onset of $\mathrm{CO}$ oxidation starts at lower potentials.

Chen et al. found that the presence of $\mathrm{IrO}_{2}$ thin film in $\mathrm{Ti} / \mathrm{IrO} 2 / \mathrm{Pt}$ nanoparticles promotes $\mathrm{CO}$ oxidation at a much lower electrode potential than $\mathrm{Pt}[10]$. The analysis of methanol oxidation on PtRuOsIr alloys revealed that the addition of $\mathrm{Ir}$ appears to accelerate the activation of the $\mathrm{C}-\mathrm{H}$ bonds of the alcohol [20].

The linear sweep voltammograms at $0.010 \mathrm{~V} \mathrm{~s}^{-1}$ and $60^{\circ} \mathrm{C}$ for EO, employing $\mathrm{PtSn} / \mathrm{C}, \mathrm{IrSn} / \mathrm{C}$, and $\mathrm{PtSnIr} / \mathrm{C}$ as catalysts are shown in Fig. 3a. It can be seen that PtSnIr/C catalyst shows the highest performance for EO. The higher catalytic activity follows the order $\mathrm{PtSnIr} / \mathrm{C}>\mathrm{PtSn} / \mathrm{C}>$ $\mathrm{IrSn} / \mathrm{C}$. At first glance, it is supposed that there is a synergic effect between $\mathrm{Pt}$, Ir, and Sn to carry out the EO reaction. Besides, straightforward participation of the oxide-metal interface in the catalytic alcohol oxidation process has been recognized by different researchers $[13,22]$ It has been also demonstrated that metal oxides can help in the dissociation of water [23]. Thus, the higher activity for EO employing the $\mathrm{PtSnIr} / \mathrm{C}$ catalyst can be attributed to a synergetic effect of $\mathrm{Sn}$ (or $\mathrm{SnO}_{2}$ ) and $\mathrm{Ir}$ (or $\mathrm{IrO}_{2}$ ) on the surface causing the dissociation of water and providing the extra oxygen required for the oxidative removal of species adsorbed on adjacent Ptactive sites. It is important to stress that many O-adsorbing metals can produce negative effects, e.g., inhibit alcohol adsorption or may be not sufficiently stable for long-term use in acid media [24].

\section{Chronoamperometry}

In Fig. 3b, the chronoamperograms at $0.50 \mathrm{~V}$ for EO show highest currents for PtSnIr/C catalyst. The current values, which are very high at the beginning, decrease rapid before reaching quasistabilization. A soft decrease is observed at longer times. The temporal stabilization of the oxidation ethanol current is an important factor for employing the catalysts in a DEFC [2].

\section{Electrochemical impedance spectroscopy}

The electrochemical impedance spectra carried out at $0.50 \mathrm{~V}$ for $\mathrm{PtSnIr} / \mathrm{C}$ and PtSn/C (Fig. 4a) and at $0.55 \mathrm{~V}$ for PtSnIr/C and IrSn/C (Fig. 4b) are shown as Nyquist plots. In both plots, it can be observed that the smaller semicircle fitted the $\mathrm{PtSnIr} / \mathrm{C}$ data. It is generally predicted that the lower the charge transfer resistance, the better the catalyst. Some researchers claimed that $\mathrm{Sn}$ and Ir activate water dissociation at lower potentials than on platinum, leading to the formation of $\mathrm{OH}$ species and promoting EO according to the bifunctional mechanism [25].

Impedance spectra of $\mathrm{EO}$ for PtSnIr/C at $60{ }^{\circ} \mathrm{C}$ and different applied potentials varying from 0.40 to $0.850 \mathrm{~V}$ are shown in Fig. 4c. At $0.40 \mathrm{~V}$, a semicircle in the complex plane with impedance values in the fourth quadrant at low frequency is observed. It is assumed that ethanol is adsorbed and dehydrogenated on $\mathrm{Pt}$ sites to produce intermediate species, which are difficult to oxidize. At $0.45 \mathrm{~V}$, the
Fig. 3 a Linear sweep voltammetry at $0.010 \mathrm{~V} \mathrm{~s}^{-1}$ for $\mathrm{EO}$ at $60^{\circ} \mathrm{C}$ for $\mathrm{PtSnIr} / \mathrm{C}$, $\mathrm{PtSn} / \mathrm{C}$ and $\mathrm{IrSn} / \mathrm{C}$; b chronoamperograms at $E=$ $0.50 \mathrm{~V}$ and $60^{\circ} \mathrm{C}$ for $\mathrm{PtSnIr} / \mathrm{C}$, $\mathrm{PtSn} / \mathrm{C}$ and $\mathrm{IrSn} / \mathrm{C}$ a

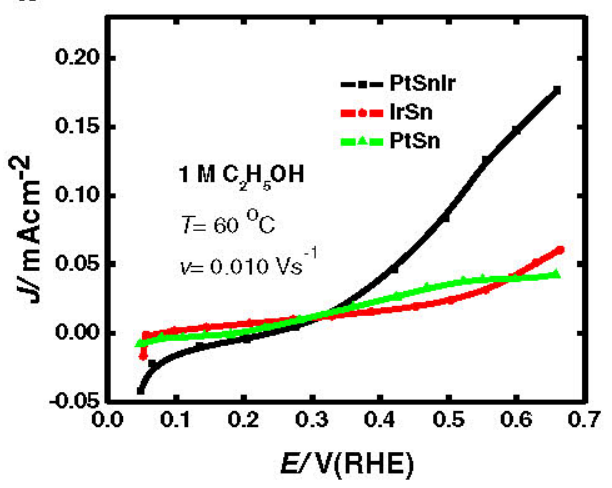

b

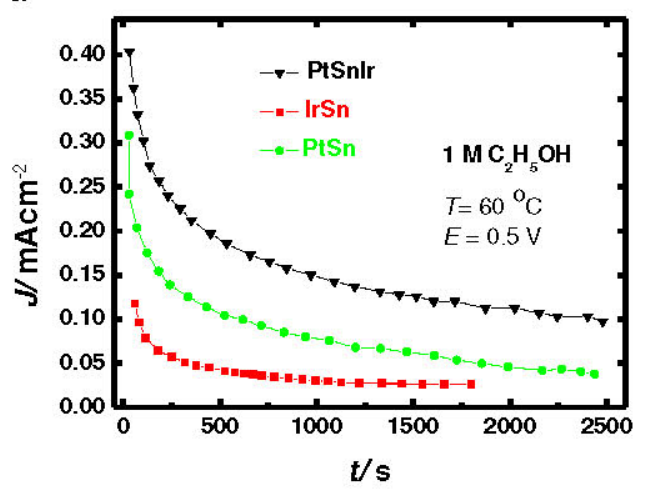


Fig. 4 EIS spectra for $\mathrm{EO}$ at $60^{\circ} \mathrm{C}$ for a $\mathrm{PtSn} / \mathrm{C}$ and $\mathrm{PtSnIr} / \mathrm{C}$ at $E=0.50 \mathrm{~V}$ and $\mathbf{b} \mathrm{PtSnIr} / \mathrm{C}$ and $\mathrm{IrSn} / \mathrm{C}$ at $E=0.55 \mathrm{~V}$ and $($ c $)$ $\mathrm{PtSnIr} / \mathrm{C}$ at $E=0.40 \mathrm{~V}$ (blue), $0.45 \mathrm{~V}$ (moss green), $0.50 \mathrm{~V}$ (cyan), $0.55 \mathrm{~V}$ (green), $0.65 \mathrm{~V}$ (pink), $0.75 \mathrm{~V}$ (orange), $0.85 \mathrm{~V}$ (dark blue)
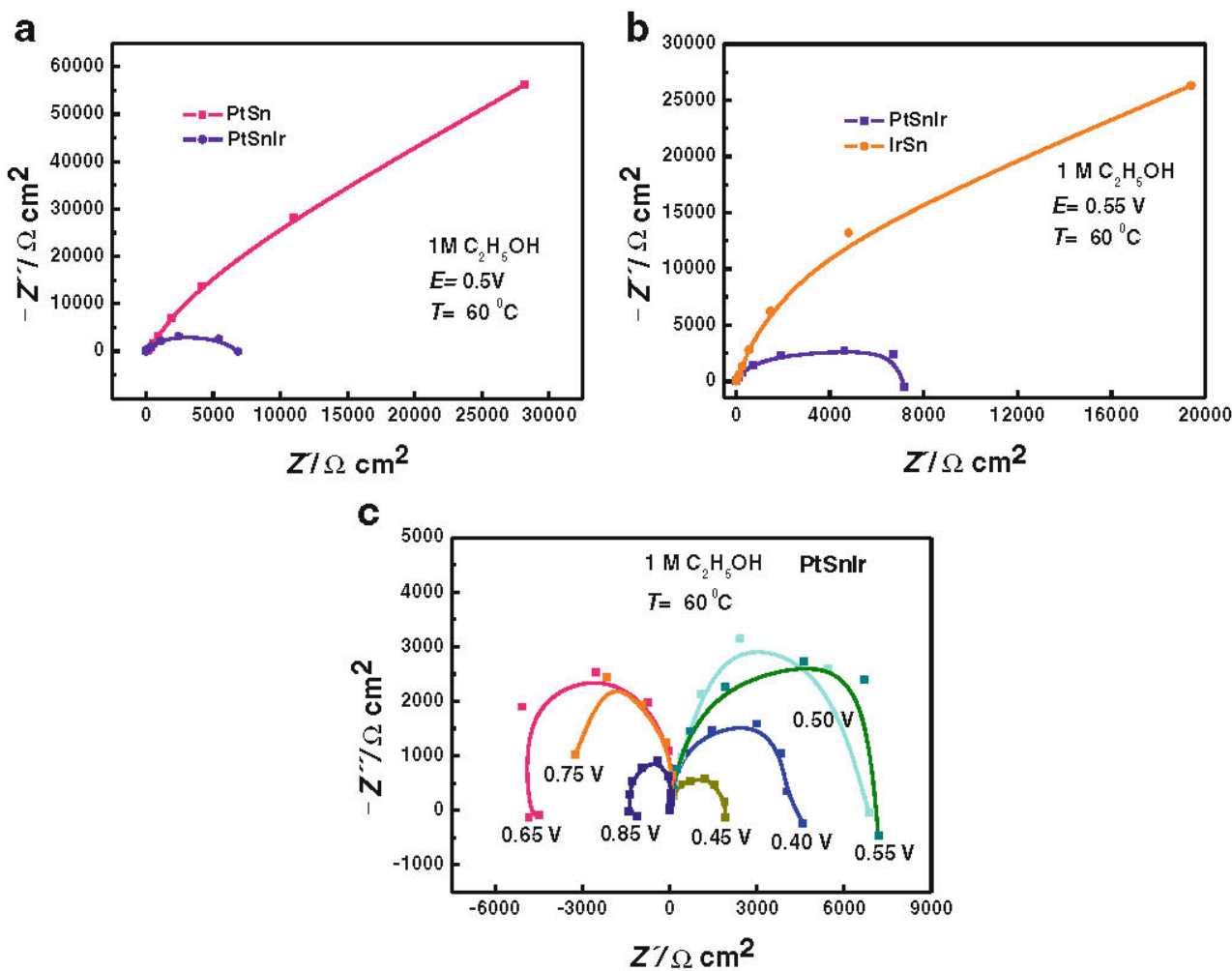

diameter of the semicircle decreases indicating that the charge transfer rate increases with increasing potential. In addition, the inductive loop at low frequencies can be attributed to changes in the rate-determining step. Thus, the oxidation of adsorbed intermediates is expected [13, 15, 23, 24]. Liang et al. claimed that the microwave-irradiated polyol plus annealing prepared PtRuIr/C catalyst displayed an enhanced activity for $\mathrm{CO}_{\mathrm{ads}}$ electro-oxidation [26]. The reaction rate increases with potential and there is a competition between fresh ethanol and water molecules for the liberated $\mathrm{Pt}$ sites and thus as the oxidation reaction progresses, the $\mathrm{Pt}$ catalytic sites are occupied either by new ethanol molecules or water molecules. It is well established that to accomplish the oxidation of ethanol, the reactants and adsorbed intermediates need to assemble $\mathrm{M}-\mathrm{OH}$ species produced by dissociative adsorption of $\mathrm{H}_{2} \mathrm{O}$ on the catalyst surface. When the potential increases over $0.65 \mathrm{~V}$, a sudden change in the impedance pattern happens with the arcs reversing to the second and third quadrants, and subsequent potential increments from 0.65 to $0.85 \mathrm{~V}$ show smaller arcs diameter [27]. A similar observation has already been reported by Melnick et al. [28] for methanol electro-oxidation on $\mathrm{Pt}$, which was related to the formation of oxygen species through water activation on the Pt surface. It is concluded that at higher potentials, the strong adsorption of $\mathrm{O}$-species on the catalyst surface, inhibits further EO. The role of cocatalysts as oxygen suppliers is an important factor to consider in the catalytic activity determination and it is strongly dependant on the nature of the cocatalysts as it has been shown in previous work [16].

\section{Conclusions}

- The binary $\mathrm{IrSn} / \mathrm{C}$ and the ternary PtSnIr/C supported catalysts synthesized by the Pechini method contain $\mathrm{Sn}$ and Ir oxides, according to physicochemical analysis. The particle size and distribution of the catalysts on carbon reveal that the Pechini method is adequate to obtain binary and ternary catalysts.

- The electrochemical characterization shows that for $\mathrm{PtSnIr} / \mathrm{C}$ catalyst, the onset potential for EO starts at lower potentials than for $\mathrm{PtSn} / \mathrm{C}$ and $\mathrm{IrSn} / \mathrm{C}$ catalysts.

- By applying different potentials in the electrochemical impedance analysis, it is possible to describe the various stages of the ethanol oxidation reaction on PtSnIr, i.e., the dehydrogenation at $E<0.50 \mathrm{~V}$ and oxidation of carbon residues $E>0.50 \mathrm{~V}$ and inhibition by through oxide formation for $E \geq 0.65 \mathrm{~V}$.

- The EIS study gives a clear evidence of the potential range where $\mathrm{PtSnIr} / \mathrm{C}$ is a useful catalyst for $\mathrm{EO}$.

Acknowledgments This work was supported by Consejo Nacional de Investigaciones Científicas y Técnicas (CONICET), Agencia Nacional de Promoción Científica y Tecnológica, Comisión de Investigaciones Científicas de la Provincia de Buenos Aires (CIC), and Universidad 
Tecnológica Nacional (UTN-FRLP). AMCL is member of the research career at CIC.

\section{References}

1. Liu H, Song C, Zhang L, Zhang J, Wang H, Wilkinson DP (2006) A review of anode catalysis in the direct methanol fuel cell. J Power Sources 155:95-110

2. Gasteiger HA, Baker DR, Carter RN, Gu W, Liu Y, Wagner FT, Yu PT (2010) Electrocatalysis and catalyst degradation challenges in proton exchange membrane fuel cells hydrogen energy. In: Stolten D (ed). Wiley: Weinheim. ISBN:9783-527-32711-9

3. Aricò AS, Baglio V, Antonucci V (2009) Direct methanol fuel cells: history, status and perspectives. In: Liu H, Zhang J (eds) Electrocatalysis of direct methanol fuel cells. Wiley, Weinheim. ISBN 978-3-527-32377-7

4. Purgato FLS, Pronier S, Olivi P, De Andrade AR, Léger JM, Tremiliosi-Filho G, Kokoh KB (2012) Direct ethanol fuel cell: electrochemical performance at $90{ }^{\circ} \mathrm{C}$ on $\mathrm{Pt}$ and $\mathrm{PtSn} / \mathrm{C}$ electrocatalysts. J Power Sources 198:95-99

5. Antolini E (2007) Catalysis for direct ethanol fuel cells. J Power Sources 170:1-12

6. Heinen M, Jusys Z, Behm RJ (2010) Ethanol, acetaldehyde and acetic acid adsorption/electrooxidation on a Pt thin film electrode under continuous electrolyte flow: an in situ ATR-FTIRS flow cell study. J Phys Chem C 114:9850-9864

7. Colmati EF, Antolini E, Gonzalez ER (2006) Effect of temperature on the mechanism of ethanol oxidation on carbon supported PtRu and $\mathrm{Pt}_{3} \mathrm{Sn}$ electrocatalysts. J Power Sources 157:98-103

8. Jiang L, Colmenares L, Jusys Z, Sun GQ, Behm RJ (2007) Ethanol electrooxidation on novel carbon supported $\mathrm{Pt}-\mathrm{SnO}_{\mathrm{x}}-\mathrm{C}$ catalysts with varied $\mathrm{Pt}: \mathrm{Sn}$ ratio. Electrochim Acta 53:377-389

9. Ammam M, Easton EB (2012) Quaternary PtMnCuX/C (X=Fe, $\mathrm{Co}, \mathrm{Ni}$, and $\mathrm{Sn}$ ) and $\mathrm{PtMnMoX} / \mathrm{C}(\mathrm{X}=\mathrm{Fe}, \mathrm{Co}, \mathrm{Ni}, \mathrm{Cu}$ and $\mathrm{Sn}$ ) alloys catalysts: synthesis, characterization and activity towards ethanol electrooxidation. J Power Sources 215:188-198

10. Chen A, La Russa DJ, Miller B (2004) Effect of the iridium oxide thin film on the electrochemical activity of platinum nanoparticles. Langmuir 20:9695-9702

11. Cao L, Sun G, Li H, Xin Q (2007) Carbon-supported IrSn catalysts for a direct ethanol fuel cell. Electrochem Commun 9:2541-2546

12. Freitas RG, Antunes EP, Christensen PA, Pereira EC (2012) The influence of $\mathrm{Ir}$ and $\mathrm{Pt}_{1} \mathrm{Ir}_{1}$ structure in metallic multilayers nanoarchitectured electrodes towards ethylene glycol electrooxidation. J Power Sources 214:351-357

13. Calegaro ML, Suffredini HB, Machado SAS, Avaca LA (2006) Preparation, characterization and utilization of a new electrocatalyst for ethanol oxidation obtained by the sol-gel method. J Power Sources 156:300-305

14. Ribeiro J, dos Anjos DM, Kokoh KB, Coutanceau C, Leger JM, Olivi P, de Andrade AR, Tremiliosi-Filho G (2007) Carbonsupported ternary PtSnIr catalysts for direct ethanol fuel cell. Electrochim Acta 52:6997-7006

15. Pechini PM, United States Patent Office 1967, 3330697

16. Bonesi AR, Moreno MS, Triaca WE, Castro Luna AM (2010) Modified catalytic materials for ethanol oxidation. Int J Hydrogen Energy 35:5999-6004

17. Paulus UA, Schmidt TJ, Gasteiger HA, Behm RJ (2001) Oxygen reduction on a high-surface area Pt/Vulcan carbon catalyst: a thinfilm rotating ring-disk electrode study. J Electroanal Chem 495:134-145

18. Bates SP (2002) Full-coverage adsorption of water on SnO2 (110): the stabilization of the molecular species. Surf Sci 512:29-36

19. Tayal J, Rawat B, Basu S (2011) Bimetallic and trimetallic $\mathrm{PtSn} / \mathrm{C}$, $\mathrm{PtIr} / \mathrm{C}, \mathrm{PtIrSn} / \mathrm{C}$ catalysts for electro-oxidation of ethanol in direct ethanol fuel cell Int. J Hydrogen Energy 36:14884-14897

20. Gurau B, Viswanathan R, Liu R, Lafrenz T, Ley K, Smotkin ES, Reddington E, Sapienza A, Chan BC, Mallouk T, Sarangapani S (1998) Structural and electrochemical characterization of binary, ternary, and quaternary platinum alloy catalysts for methanol electro-oxidation. J Phys Chem B 102:9997-10003

21. Stamenkovic V, Arenz M, Blizanac BB, Mayrhofer KJJ, Ross PN, Markovic NM (2005) In situ CO oxidation on well characterized $\mathrm{Pt}_{3} \mathrm{Sn}(\mathrm{hkl})$ surfaces: a selective review. Surf Sci 576:145-157

22. Barretto C, Parreira R, Goncalves R (2008) Platinum nanoparticles embedded in layer-by-layer films from $\mathrm{SnO} 2 /$ polyallylamine for ethanol electrooxidation. J Power Sources 185:6-12

23. Ye F, Li J, Wang T, Liu Y, Wei H, Li J, Wang X (2008) Electrocatalytic properties of platinum catalysts prepared by pulse electrodeposition method using $\mathrm{SnO} 2$ as an assisting reagent. J Phys Chem C 112:12894-12898

24. Wu G, Li L, Xu B (2004) Effect of electrochemical polarization of $\mathrm{PtRu} / \mathrm{C}$ catalysts on methanol electrooxidation. Electrochim Acta 50:1-10

25. Watanabe M, Motoo S (1975) Electrocatalysis by ad-atoms: Part III. Enhancement of the oxidation of carbon monoxide on platinum by ruthenium ad-atoms. J Electroanal Chem 60:275-283

26. Liang $\mathrm{Y}$, Zhang $\mathrm{H}$, Zhong $\mathrm{H}$, Zhu X, Tian Z, Xu D, Yi B (2006) Preparation and characterization of carbon-supported PtRuIr catalyst with excellent CO-tolerant performance for proton-exchange membrane fuel cells. J Catal 238:468-476

27. Lasia C (2012) Dynamic impedance study of ethanol and acetaldehyde oxidation at platinum in acid solutions. Electrochim Acta $78: 286-293$

28. Melnick RE, Palmore GTR (2001) Time-dependent impedance of the electro-oxidation of methanol on polished polycrystalline platinum. J Phys Chem B 105:9449-9457 